\title{
DOMESTICATION OF TREES BY UPLAND FARMERS IN SOUTHERN LEYTE, PHILIPPINES
}

\author{
ANATOLIO N. POLINAR \\ Visayas State University, Visca, Baybay, Leyte
}

\section{ABSTRACT}

The study was conducted to determine the species of trees that are domesticated by upland farmers in Southern Leyte through interview and field visitation. It also looked into the reasons how trees become established in their farms and what influences their attitudes towards tree domestication.

Timber and fruit tree species were both domesticated by farmers. Seedlings from nursery were planted and trees from natural regeneration were reared in farm lots. Thirteen (13) timber species, in 12 genera and 8 families and 23 fruit tree species, in 19 genera and 15 families, were recorded as domesticated intentionally through actual planting. Eighteen (18) timber-producing and 38 non-timber producing tree species were recorded as domesticated through rearing of naturally occurring trees. The reared timber trees included 8 dipterocarp species. Mahogany (Swietenia macrophylla King) and yemani (Gmelina arborea Roxb.) were the most commonly planted exotic timber species. Molave (Vitex parviflora Juss.) was the most preferred native timber species while mango (Mangifera indica Lin.) was the most preferred fruit tree for on-farm domestication.

Availability of suitable land for planting of trees, small farm size, unclear land tenure, availability of planting materials and unclear government policy on harvesting of planted trees were the most relevant factors that cause many farmers to refrain from adopting tree domestication.

\section{KEY WORDS: Tree domestication. Tree farming. Tree diversity}




\section{INTRODUCTION}

The Philippine uplands provide a wealth of timber and non-timber forest products, many of which have been traditionally used by the upland people for generations. Now, availability of these products is continuously confronted with problems. The status of biological diversity, specifically in trees, is globally a critical issue for present-time conservationists. Large areas of forests are replaced by grassland and other land uses. Massive forest conversion is threat to the existence of flora and deprives valuable species from getting established again. As natural forest systems recede, it is also recognized that some of their component species become adapted to and are finding refuge in human-induced ecosystems such as the upland farm lots. In what species mixture and how these species are maintained remain poorly documented.

Various government programs had been supportive to tree domestication. Among them is the promotion of tree planting and reforestation among farmers, both in the lowland and highland areas of the Philippines. In the tropics, interest in tree plantation establishment is increasing rapidly (Evans, 1986). People in many areas have long been involved in the conservation and cultivation of trees in agricultural and forested lands. Even ordinary farmers at subsistence status are actively involved in these initiatives to help mitigate the worsening condition of forest resources.

The extent to which people cultivate and manage trees varies from place to place. Tree crops are integrated in agroforestry systems to increase the variety and diversity of species cultivated. Having more diverse systems is achieved by bringing more forest species that are traditionally used by local people into cultivation. This made conservation of the remaining forest 
areas vital to ensure the availability of genetic resources for future needs of tree domestication. This study was conducted to determine the tree species that are preserved through domestication in Southern Leyte, the farmer preference among tree species and the factors that influence farmer attitude towards tree domestication.

\section{METHODOLOGY}

The study was conducted in six selected barangays in Southern Leyte. These were: Calag-itan, Hinunangan; Hindag-an, Saint Bernard; Nahulid, Libagon; Anahaw, Bontoc; Kahupian, Sogod and Malapoc Norte, Maasin City. Forty farmer respondents were randomly selected in each barangays based on barangay profile and available lists of upland farmers. Community leaders were used as key informants in the identification and final selection of respondents.

Data were gathered through individual household survey using a semistructured interview schedule. Open ended questions were used to maintain the activeness of respondent in the discussion. This was followed by actual farm visits, with accompaniment by the respondents. Interview results on species claimed to be domesticated were counter-checked or validated in the field inspection. Descriptive statistics, such frequency, rank and total, were used in data presentation.

\section{RESULTS AND DISCUSSION}

\section{Tree Species under domestication}

The species that were found domesticated in the study area included the trees that are planted intentionally and trees that naturally occur on farm 
lots. Trees that naturally occur through regeneration are deliberately not removed and reared to continue growing due to perceived value of future products. There were 36 species that were directly planted and 67 species that were reared (Table 1). Among the planted species, fruit trees were the most common (23) compared to native (7) and exotic (6) timber species. Among the reared naturally regenerated trees, pioneer species was highest in number: Commercially important timber species (18) were also recorded as naturally regenerated and reared. Regeneration of native timber species was an indication that the study area was not far away from the natural forests. The table indicated that in planting farmers choose species that have clear beneficial products, either fruit or timber. In rearing regenerated trees, even the species known as not good for lumber production had the chance of being conserved.

Table 1. The number of species planted and reared, by category.

\begin{tabular}{|c|c|c|}
\hline TREE CATEGORY & PLANTED & REARED \\
\hline Fruit trees & 23 & - \\
\hline Exotic timber & 6 & - \\
\hline Commercial timber-producing native trees & 7 & 18 \\
\hline Non-timber producing native trees & - & 11 \\
\hline Pioneer trees & & 38 \\
\hline Total & 36 & 67 \\
\hline
\end{tabular}

\section{Fruit tree species}

Mango (Mangifera indica) was the most frequently mentioned among the planted fruit species (Table 2). It was followed in frequency by nangka (Artocarpus heterophylla), cacao (Teobroma cacao) and coffee (Coffea arabica). Majority of the fruit tree species, 17 out of the 23 , were claimed as planted in residential lots and the other 6 in farm lots. Distance from residence, expected products from the planted species and availability of 
planting materials had been the major considerations in deciding the fruit trees to plant and where they are planted. Mango, durian, rambutan and marang banguhan were claimed as having been planted in farm lots five years earlier due to acquisition of asexually propagated seedlings through project.

Table 2. Response frequency by farmers on fruit trees planted in Southern Leyte.

\begin{tabular}{lllc}
\hline COMMON NAME & \multicolumn{1}{c}{ SCIENTIFIC NAME } & FAMILY NAME & $\begin{array}{c}\text { FREQUENCY } \\
(\mathrm{N}=240)^{*}\end{array}$ \\
\hline 1. Mangga & Mangifera indica & Anacardiaceae & 96 \\
2. Nangka & Artocarpus heterophylla & Moraceae & 88 \\
3. Cacao & Theobroma cacao & Sterculiaceae & 82 \\
4. Kape & Coffea Arabica & Rubiaceae & 81 \\
5. Guava & Psidium guajava & Myrtaceae & 76 \\
6. Tambis & Syzygium aqueum & Myrtaceae & 70 \\
7. Makopa & Syzygium samarangense & Myrtaceae & 49 \\
8. Marang banguhan & Artocarpus odoratissima & Moraceae & 45 \\
9. Lanzones & Lansium domesticum & Meliaceae & 43 \\
10. Santol & Sandoricum koetjape & Meliaceae & 42 \\
11. Star apple & Chrysophyllum cainito & Sapotaceae & 39 \\
12. Lemonsito & Triphasia trifolia & Rutaceae & 38 \\
13. Durian & Durio zibethinus & Bombacaceae & 36 \\
14. Rambutan & Nephellium lappaceum & Sapindaceae & 33 \\
15. Guyabano & Annona muricata & Annonaceae & 29 \\
16. Avocado & Persea americana & Lauraceae & 25 \\
17. Kamagong & Diospyros philippinensis & Ebenaceae & 19 \\
18. Mamon & Annona glabra & Annonaceae & 18 \\
19. Lukban & Citrus grandis & Rutaceae & 17 \\
20. Chico & Manilkara zapota & Sapotaceae & 15 \\
21. Atis & Annona squamosa & Annonaceae & 13 \\
22. Balimbing & Averrhoa carambola & Oxalidaceae & 10 \\
23. Mansanitas & Ziziphus mauritianus & Rhamnaceae & 7 \\
\hline
\end{tabular}




\section{Timber tree species}

The response frequency on the planting of native and exotic timber trees on per species basis is shown in Table 3. The exotics, big-leafed mahogany (Swietenia macrophylla) and yemani (Gmelina arborea), were the most frequently planted timber species. Acacia mangium, Eucalyptus camaldulensis, Tectona grandis and Paraserianthes falcataria were the other planted exotics but at moderate frequencies. The most commonly planted native timber species was narra (Pterocarpus indicus) though it had only moderate response frequency. Only 3 traditional commercial timber species, lanipga (Toona philippinensis), white lauan (Shorea contorta) and tanguile (Shorea polysperma) were recorded as planted and they all had markedly low response frequency. Molave (Vitex parviflora), auri (Acacia auriculiformis), ipil-ipil (Leucaena leucocephala) and toog (Petersianthus quadrialatus) were not mentioned in the interview but seen as planted during the field visits. This implies that higher number of species could have been planted or reared by farmers than they could recall during the interview.

\section{Naturally growing timber species}

Eighteen (18) species, in 6 families and 8 genera, were recorded during visits to farmers field (Table 4). The family Dipterocarpaceae had the highest number of species (8) recorded. The naturally regenerated trees were found concentrated in farm boundaries and areas adjoining forest. Dipterocarps were also growing in abandoned kaingin and successional areas although these are not part of the sites where tree domestication was actually practiced. High number of mother trees and adequate supply of wildlings were observable in the vicinity, which may explain the occurrence 
Table 3. Response frequency by farmers on planted timber species in Southern Leyte

\begin{tabular}{lllc}
\hline \multicolumn{1}{c}{ COMMON NAME } & \multicolumn{1}{c}{ SCIENTIFIC NAME } & \multicolumn{1}{c}{ FAMILY } & $\begin{array}{c}\text { FREQUENCY } \\
(\mathrm{n}=240)\end{array}$ \\
\hline $\begin{array}{llll}\text { 1. Large leaf } \\
\text { mahogany }\end{array}$ & Swietenia macrophylla & Meliaceae & 154 \\
2. Yemani & Gmelina arborea & Verbenaceae & 143 \\
3. Narra & Pterocarpus indicus & Fabaceae & 85 \\
4. Mangium & Acacia mangium & Mimosaceae & 76 \\
5. Eucalyptus & Eucalyptus camaldulensis & Myrtaceae & 60 \\
6. Bagalunga & Melia dubia & Meliaceae & 53 \\
7. Mollucan sau & Paraserianthes falcataria & Fabaceae & 48 \\
8. Banaba & Lagerstroemia speciosa & Lythraceas & 27 \\
9. Teak & Tectona grandis & Verbenaceae & 21 \\
10. Agoho & Casuarina equisitefolia & Casuarinaceae & 18 \\
11. Lanipga & Toona philippinensis & Meliaceae & 9 \\
12. White lauan & Shorea contorta & Dipterocarpaceae & 6 \\
13. Tanguile & Shorea polysperma & Dipterocarpaceae & 3 \\
\hline
\end{tabular}

of premium timber species in natural regeneration to farmer's field and the availability of their seedlings for planting in the locality.

Thirty eight (38) pioneer tree species were recorded during farmers' interview and field visitation. Moraceae was the family that got the highest representation among pioneer species. This was followed by Euphorbiaceae, Apocynaceae, Lauraceae, Fagaceae and Sterculiaceae. Some of the pioneer species are of primary importance to farmers while others were considered nuisance to farm since they compete with the main crop. Several attempts had been made by farmers to eradicate some of these species but then it remained unsuccessful considering that some pioneers are prolific seed producers and had excellent sprouting ability. In some cases, a number of species although of low in economic value were 
value were claimed as conserved primarily for firewood and erosion control measures. Ani-i (Erythrina fusca) is among the non-timber species that was also conserved by farmers in Southern Leyte, along with abaca (Musa textiles). The tree was praised as important by farmers in providing shade and organic fertilizer to abaca.

Table 4. Commercially important timber- producing tree species in the vicinity of farm lots during field visits in Southern Leyte

\begin{tabular}{lll}
\hline \multicolumn{1}{c}{ COMMON NAME } & \multicolumn{1}{c}{ SCIENTIFIC NAME } & FAMLLIES \\
\hline 1. Lamio & Dracontomelon edule & Anacardiaceae \\
2. Tindalo & Afzelia rhomboidea & Caesalpiniaceae \\
3. Almon & Shorea almon & Dipterocarpaceae \\
4. Apitong & Dipterocarpus grandifforus & Dipterocarpaceae \\
5. Gisok-gisok & Hopea philippinensis & Dipterocarpaceae \\
6. Mayapis & Shorea palosapis & Dipterocarpaceae \\
7. Red lauan & Shorea negrosensis & Dipterocarpaceae \\
8. Tangile & Shorea polysperma & Dipterocarpaceae \\
9. White lauan & Shorea contorta & Dipterocarpaceae \\
10. Yakal & Shorea astylosa & Dipterocarpaceae \\
11. Anang & Diospyros pyrrhocarpa & Ebenaceae \\
12. Bolong-eta & Diospyros pilosanthera & Ebenaceae \\
13. Makaasim & Syzygium nitidum & Myrtaceae \\
14. Malabayabas & Tristania decorticata & Myrtaceae \\
15. Sagimsim & Syzygium brevistylum & Myrtaceae \\
16. Tiga & Tristania micrantha & Myrtaceae \\
17. Lingo-lingo & Vitex turczaninowii & Verbenaceae \\
18. Molave & Vitex parviflora & Verbenaceae \\
\hline
\end{tabular}

\section{Non-timber producing species}

The non timber producing species that are reared were predominantly pioneers. These trees were found widely distributed in the vicinity of the farmer's field (Table 5). During field visitation many species were found growing in newly abandoned and fallowed kaingin areas. However, not all 
Table 5. Non-timber producing tree species found in the vicinity of farmres' field

\begin{tabular}{|c|c|c|c|c|}
\hline No. & FAMILIES & COMMON NAME & SCIENTIFIC NAME & \\
\hline 1 & Anacardiaceae & Libas & Spondias pinnata & \\
\hline 2 & Annonaceae & llang-ilang & Osmanga odorata & \\
\hline 3 & Apocynaceae & Balobo & Diplodiscus paniculatus & \\
\hline 4 & Apocynaceae & Dita & Alstonia scholaris & \\
\hline 5 & Apocynaceae & Lanite & Wrightia pebescens & \\
\hline 6 & Euphrobiaceae & Balanti & Homolanthus populneus & \\
\hline 7 & Euphrobiaceae & Banato & Mallotus philippinensis & \\
\hline 8 & Euphrobiaceae & Bantilong & Calophyllum blancoi & \\
\hline 9 & Euphrobiaceae & Binunga & Macaranga canaries & \\
\hline 10 & Euphrobiaceae & Hinlaumo & Mallotus ricinoides & \\
\hline 11 & Euphrobiaceae & Kasla & Croton lancilimbus & \\
\hline 12 & Fabaceae & Ant-i & Enthrina fusca & \\
\hline 13 & Fabaceae & Bahai & Ormosia calavensis & \\
\hline 14 & Fagaceae & Pangnan & Lithocarpus sulitii & \\
\hline 15 & Fagaceae & Tapotasa & Lithocarpus submonticolus & \\
\hline 16 & Fagaceae & Ulaian & Lithocarpus Ilonosii & \\
\hline 17 & Gutifereae & Bitanghol & Calophyllum blancoi & \\
\hline 18 & Gutifereae & Bitanghol sibat & Calophyllum lancifollum & \\
\hline 19 & Lauraceae & Bakan & Litsea philippinensis & \\
\hline 20 & Lauraceae & Kalingag & Cinnamomum mercadoi & \\
\hline 21 & Lauraceae & Marang & Litsea perrottettii & \\
\hline 22 & Moraceae & Alangas & Ficus heteropoda & \\
\hline 23 & Moraceae & Balete & Ficus balete & \\
\hline 24 & Moraceae & Hagimit & Ficus minahassae & \\
\hline 25 & Moraceae & Hauili & Ficus septica & \\
\hline 26 & Moraceae & Is-is & Ficus ulmifolia & \\
\hline 27 & Moraceae & Pakiling & Ficus odorata & \\
\hline 28 & Moraceae & Tibig & Ficus nota & \\
\hline 29 & Rhamnaceae & Tulo & Alphitonia philippinensis & \\
\hline 30 & Myristicaceae & Duguan & Myrisctica philippninses & \\
\hline 31 & Myristicaceae & Tanghas & Myristica elliptica & \\
\hline 32 & Rubiaceae & Lisak & Neonauclea bartingii & - \\
\hline 33 & Rubiaceae & Hambabalud & Neonauclea formicaria & \\
\hline 34 & Sterculiaceae & Bayok & Pterospermum diversifolium & \\
\hline 35 & Sterculiaceae & Suyapau & Commersonia bartramia & \\
\hline 36 & Sterculiaceae & Taluto & Pterocymbium tinctorium & \\
\hline 37 & Tileaceae & Anllao & Colona serratifolia & \\
\hline 38 & Verbenaceae & Alagaw & Premna odorata & \\
\hline
\end{tabular}


species found in farm boundaries also occur along roadsides. This suggests that certain species may seek varied site conditions.

\section{Farmer tree preferences}

Table 6 presents the farmers commonly most preferred fruit trees and timber species for domestication. Molave (Vitex parviflora) got the highest rank. It was followed by narra (Pterocarpus indicus), yemani (Gmelina arborea), mangium (Acacia mangium) and red lauan (Shorea negrosensis). Preferences on timber tree species by the respondents were influenced by quality and physical appearance of wood, utilization potential, market demand of lumber/logs and availability of seeds and plantable planting materials.

In fruit trees, mango (Mangifera indica) ranked highest. This was followed by lanzones (Lansium domesticum), tambis (Syzygium agueum), and nangka (Artocarpus heterophylla) and lemonsito (Triphasia trifolia). According to farmers, characteristics and productivity had given them the encouragement to domesticate fruit trees for food and additional income.

Table 7 shows the primary reasons for farmers to refrain from planting trees and from conserving naturally growing trees in their farms. A total of $228(95 \%)$ respondents had expressed sentiments that availability of land was the primary reason for not planting and conserving trees. Some farmers were planting trees only in limited number. This has also resulted from DENR strict implementation of forest policies against shifting cultivation in forested areas. Most of the respondents were forest occupants who depend on forests as dwelling place for their livelihood undertakings. Another issue was security of tenure on the land they cultivate. Majority of 
Table 6. Preferred fruit tree and timber tree species for domestication

\begin{tabular}{lclc}
\hline FRUIT SPECIES & $\begin{array}{c}\text { FREQUENCY } \\
\left(n=240^{*}\right)\end{array}$ & \multicolumn{1}{c}{ TIMBER SPECIES } & $\begin{array}{c}\text { FREQUENCY } \\
\left(\mathrm{n}=240^{*}\right)\end{array}$ \\
\hline 1. Mango & 206 & 1. Molave & 186 \\
2. Lanzones & 178 & 2. Narra & 179 \\
3. Tambis & 164 & 3. Yemani & 160 \\
4. Nangka & 144 & 4. Mangium & 133 \\
5. Limonsito & 134 & 5. Red lauan & 125 \\
6. Caimito & 127 & 6. Large leaf mahogany & 120 \\
7. Rambutan & 115 & 7. Tangile & 115 \\
8. Guava & 87 & 8. White lauan & 113 \\
9. Atis & 79 & 9. Bagalunga & 110 \\
10. Makopa & 74 & 10. Auri & 98 \\
11. Coffee & 72 & 11. Almon & 96 \\
12. Durian & 66 & 12. Mayapis & 93 \\
13. Cacao & 65 & 13. Molucan sau & 90 \\
14. Santol & 63 & 14. Agoho & 85 \\
15. Avocado & 60 & 15. Lanipga & 68 \\
16. Guyabano & 59 & 16. Ipil-ipil & 62 \\
17. Marang banguhan & 55 & 17. Teak & 59 \\
18. Lukban & 51 & 18. Tindalo & 45 \\
19. Balimbing & 37 & 19. Sudiang & 39 \\
20. Chico & 32 & 20. Lingo-lingo & 34 \\
21. Sunkist & 28 & 21. Ani-i & 30 \\
22. Mamon & 27 & 22. Sagimsim & 28 \\
\hline 23. Manzanitas & 24 & 23. Toog & 23 \\
\hline
\end{tabular}

*Multiple response

the respondents $(66 \%)$ do not own the lots they farm. Most farm sizes were small, such that $45 \%$ (107 parcels) are less than 0.50 hectare and 30\% (72 parcels) are $0.51-1$ hectare only (Polinar, 2004). The farm lots were too small and would be further reduced if any part of it would be allocated to trees. Expansion of landholdings was also constrained by strict regulation of farming in the timber land by the DENR. 
Readily available planting materials can induce the farmers to plant trees. They seldom plant trees when asked to find or produce their own seedlings. Thus, species of planted trees are highly influenced by what were easier to procure or what were readily available. Though government policies now allow harvesting and utilization of planted timber trees, awareness level on these is low. The lack of access to technology, farm inputs, equipment and unstructured timber markets were the other reasons of upland farmers not to engage in planting of trees.

Table 7. Reasons that hinder farmers to engage in tree domestication

\begin{tabular}{lc}
\hline \multicolumn{1}{c}{ Variable } & $\begin{array}{c}\text { Responses } \\
\left(\mathrm{n}=\mathbf{2 4 0 ) ^ { * }}\right.\end{array}$ \\
\hline Land available for trees & 228 \\
Smaller farm size & 228 \\
Unclear land tenure & 215 \\
Availability of planting materials & 181 \\
DENR policy on planting and harvesting of trees & 165 \\
Availability of tree farming technology & 128 \\
Unclear market of forest products & 119 \\
Waiting time to harvest is too long & 107 \\
Financial capability to invest in timber & 97 \\
Accessibility of suitable sites for trees & 81 \\
Poor soil condition & 69 \\
\hline *Multiple responses &
\end{tabular}

\section{Conclusions}

\section{CONCLUSION AND RECOMMENDATION}

Based on results in interview and farm visitation in selected communities in Southern Leyte the following conclusions were drawn: 
1. The farmers had been planting only a modest number of timber and fruit tree species on farm. Large leaf mahogany (Swietenia macrophylla) and yemani (Gmelina arborea) were the most commonly planted exotic species. Molave (Vitex parviflora) was the most preferred native timber species while mango (Mangifera indica) was the most preferred fruit tree;

2. A total of 18 timber and 38 non-timber species from natural regeneration in origin were reared by farmers' in Southern Leyte. Non-timber species, including any pioneer species were found persistent in farms, apparently for some being as obnoxious weeds;

3. The diversity of tree species used in planting was primarily dependent on species of seedlings that were readily available;

4. The diversity of tree species that were reared depended primarily on degree of regeneration and their attitude to remove them through brushing or weeding. Tree species that are viewed as valuable for timber and firewood have better chance of being reared to grow bigger and stay in the farm;

5. Land availability, farm size and securities in land tenure were the primary constraints for farmers to domesticate trees.

\section{Recommendations}

Based on the study results the following were recommended:

1. Studies to determine what type of sites or part of land parcels where farmers usually allow regenerated trees to grow and where they are willing to incorporate trees; 
2. Information on recent tree farming technology and government policy that can enhance domestication need to be widely disseminated; and,

3. Studies on how to resolve land availability for tree domestication need to be conducted.

\section{LITERATURE CITED}

EVANS, J. 1986. Plantation Forestry in the tropics. Oxford University Press, New York. 472pp.

POLINAR, A.N. and A.C.Y.SANDOVAL. 2004. Factors in the adoption of tree conservation practices by upland farmers in Southern Leyte. Sci. and Hum. Journal. 1(4):40-51

ROJO, J. 1999. Lexicon of PhilippineTrees. FPRDI, DOST, College, Laguna, 4031 Philippines, pp.484. 